\title{
Nanostructural Modification of Polytetrafluoroethylene and its Composition by Energy Influence
}

\author{
K.V. Berladir ${ }^{1}$, T.P. Hovorun ${ }^{1}$, V.A. Sviderskiy ${ }^{2}$, P.V. Rudenko ${ }^{1}$, M.E. Vyshehorodtseva ${ }^{1}$ \\ 1 Sumy State University, 2, Rymskogo Korsakova St., 40007 Sumy, Ukraine \\ 2 National Technical University of Ukraine "Kyiv Polytechnic Institute», 37, Peremogy Ave., 03056 Kyiv, Ukraine
}

(Received 02 February 2016; revised manuscript received 02 March 2016; published online 15.03.2016)

\begin{abstract}
Supramolecular structure and performance properties of activated matrix polytetrafluoroethylene, modified fiber filler and composites based on its are investigated. Shown that the energy influence contributes to transfer of the polytetrafluoroethylene matrix structure in nanoscale state. The technology of sequential mechanical activation of the ingredients composition before their mixing by the energy influence is developed. Nanostructured matrix, fragments of carbon fibers and their interface in the formed composite determine the unique physical, mechanical and operational characteristics of composite materials. As a result of research the material of new generation with maximum physical and mechanical and tribotechnical properties is developed.
\end{abstract}

Keywords: Polytetrafluoroethylene, Fragments of carbon fibers, Nanostructure, Activated ingredients, Mechanical activation, Properties, Material of new generation.

DOI: 10.21272/jnep.8(1).01033

PACS numbers: 81.05.Lg, 81.05.Qk, 81.07.Nb, 81.20.Ev, 82.35.Gh, 82.35.Lr, 82.35.Np

\section{INTRODUCTION}

Widespread use of polytetrafluoroethylene composites in friction units and seals of various kinds of machinery and equipment is conditioned by features of molecular and supramolecular structure of polytetrafluoroethylene (PTFE) which ensure the implementation of a unique combination of deformation and strength, tribotechnical, anticorrosive, thermophysical and other service characteristics and determine the field of efficient use of these products [1].

Specific features of molecular and supramolecular structure of PTFE determine the typical mechanisms of boundary layers which define the parameters of deformation, strength and tribotechnical characteristics of PTFE composites during the thermobaric interaction with the dispersed particulate of matrix polymer and composite material that contain functional modifiers of different nature, the elemental composition, morphology and dispersion and that allow to get rid of shortcomings base matrix [2].

Practical implementation of this direction of technology consists in ensuring the optimal structure of the boundary layer based on a comprehensive analysis of the morphology modifiers surface layers of particles modifiers, their energy options influence on the processes of adsorption and chemical adsorption interaction [3]. It causes the necessity of application special methods of active influence on the composition, primarily - mechanochemical and energy [4].

Features of operation of products with the PTFE composites usually lead to the transformation of the primary structure for a short time. Formed under the influence of external factors the new structure is significantly different from the primary and determines the resource of the products in actual use. Influence of the primary structure of PTFE composite on the kinetics of formation the distributing layer with a structure that more effectively resists acting on tribosystem the energy parameters needs a more detailed study and consid- eration of the interaction of components in determining the composition of PTFE composite.

Analysis of literary sources [1-5] showed that the potential opportunities of traditional technologies of PTFE composites aren 't implemented fully due to underestimation of significant factors in the obtaining composite and recycling it into products.

Therefore, optimization of technological modes of production and recycling of PTFE composites using available equipment allows achieving economically significant results and increases their competitiveness among the analogs.

\section{EXPERIMENTAL}

\subsection{Objects of Research}

The object of the research is powdered PTFE of F-4PN brand (GOST 10007).

As the fibrous filler used fragments of carbon fibers (CF) made from carbon fabric UTM-8 (TC 48-20-17-77) which was obtained by chemical treatment in aqueous solution of flame retardants $\mathrm{Na}_{2} \mathrm{~B}_{4} \mathrm{O}_{7} \cdot 10 \mathrm{H}_{2} \mathrm{O}+$ $\left(\mathrm{NH}_{4}\right)_{2} \mathrm{HPO}_{4}$ and annealing at a temperature of $723 \pm 20 \mathrm{~K}$ in an environment of natural gas $\mathrm{CH}_{4}$.

Test samples were obtained by cold molding technology (molding pressure $P_{\text {mold }}=50.0-70.0 \mathrm{MPa}$ ), followed by free sintering of tablet blanks in air at $638 \pm 5 \mathrm{~K}$ at a speed of heating-cooling of $40 \mathrm{~K} / \mathrm{h}$.

\subsection{Research Methodology}

Methodology of studying the composite properties included determining the density $\rho\left(\mathrm{g} / \mathrm{cm}^{3}\right)$, breaking strength $\sigma_{b}(\mathrm{MPa})$, relative elongation at break $\delta(\%)$ and wear rate $I \cdot 10^{-6}\left(\mathrm{~mm}^{3} / \mathrm{N} \cdot \mathrm{m}\right)$ as basic necessary data about the material for designers, production engineers and operating staff.

Tests of rupture strength and relative elongation at break were performed on ring samples of $50 \times 40$ diame- 
ters and $10 \mathrm{~mm}$ height using rigid half-discs at R-1 disruptive installation at the motion speed of sliding member of $0.25 \mathrm{~cm} / \mathrm{min}$.

The density $\rho$ of the samples was determined by hydrostatic weighing.

The study of the wear rate was carried out on SMT-1 serial friction machine according to "partial insertionshaft» scheme.

The magnitude of wear of the samples was determined gravimetrically on an analytical balance within the accuracy of $10^{-5}$ grams and transferred to the intensity of wear by known methodologies [6].

IR spectra of surfaces of PTFE and wear products were registered on FT-IR Nicolet 5700 spectrometer in display mode. Wear products had been previously tableted at room temperature at the pressure of $50 \mathrm{MPa}$. Absorption band of $\mathrm{CF}_{2}$ groups of PTFE was used as comparison band at $1206 \mathrm{~cm}^{-1}$. The relative error of optical density definition in a series of three measurements was $\sim 20 \%$.

The study of supramolecular structure of activated PTFE powder and composites based on it was carried out using TESCAN MIRA 3 LMU scanning electron microscope of high resolution.

Surface morphology of the fragments of CF was carried out using raster electron microscope REM-200.

Processing of experimental data was performed by the methods of mathematical design of experiments and mathematical statistics [7].

\section{RESULTS AND DISCUSSION}

\subsection{Energy Modification of PTFE Matrix}

Industrially produced PTFE is a powdered substance with a particle size to 250-300 microns which easily forms larger aggregates that limits its practical use in the manufacture of compositions, products, obtaining of lubricating materials, etc [5].

Dispersity of PTFE powdered product depends on the technology of obtaining and largely determines the effectiveness of the processability its recycling in products of constructional, tribotechnical, sealing destination by pressing with subsequent sintering. The dominant value of this parameter is at creation of PTFE compositions with the fillers of different nature and morphology.

Scientifically substantiated and practically proved that effective way to improve physical-mechanical and tribotechnical properties of PTFE is its mechanical activation in which the supramolecular structure of PTFE undergoes significant changes - from lamellar disordered in the structure with higher ordering until the spherulitic [8].

As a result of energy-active mechanical impact is chemical mechanical destruction of macromolecules of polytetrafluoroethylene with the formation of radical fragments and formation of inter-factional elements of PTFE which that form the structures that more actively resist wear and provide higher physical and mechanical properties.

It was found that the activated PTFE has the optimal ratios of physical-mechanical and tribotechnical properties in mode of $n=9 \cdot 10^{3} \mathrm{~min}^{-1}$ and $\tau=5$ minutes: brea- king strength $\sigma_{b}=24,8 \mathrm{MPa}$, relative elongation $\delta=415 \%$, wear intensity $I=610 \cdot 10^{-6} \mathrm{~mm}^{3} / \mathrm{N} \cdot \mathrm{m}[8,9]$.

Methods of electron microscopy have shown the grinding of structural components of PTFE with value of 250-300 microns in the nonactivated polymer to 10 50 microns by length and diameter from 10 to $100 \mathrm{~nm}$ in an activated polymer (Fig. 1) [9].

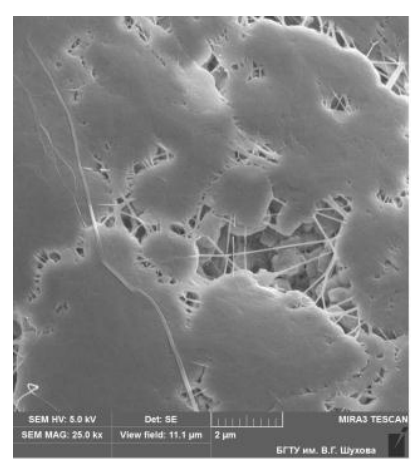

a

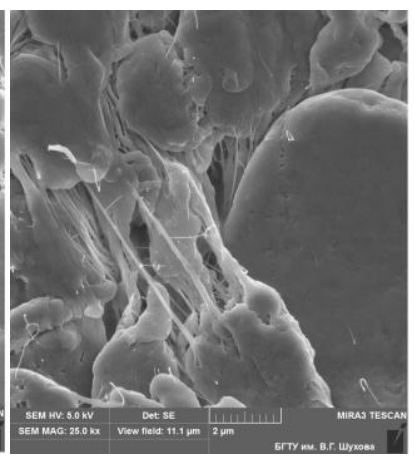

$\mathrm{b}$
Fig. 1 - Structure of PTFE before (a) and after (b) mechanical activation in mode $n=9 \cdot 10^{3} \mathrm{~min}^{-1}$ and $\tau=5$ minutes

By IR spectroscopy method it was found that in case of the PTFE modification as a result of mechanical activation, a transition of the polymer into dispersed, nanodispersed and other structural states occurs [9].

In the IR spectra of these formations, the bands that characterize the vibrations of individual fragments and whole chain even under intense energy impact are preserved. This allows assuming that the external mechanical influence does not result in noticeable destruction of polytetrafluoroethylene molecular chain, but in some cases, certain changes occur at the molecular level, which leads to enhanced physical, mechanical and service properties of the polymer and reveals the possibility to use activated PTFE as a matrix of fluoropolymer composites of various applications.

\subsection{Composites Based on Modified PTFE with Activated Filler}

Previous studies [11] of structure and properties composites based on activated PTFE matrix and carbon fibers was found that carbon fillers in relation to PTFE show structural activity and affect the morphology and the degree of ordering of the modified polymer matrix. The character and efficiency of this influence depend on reducing the sizes of elements structure, dimension of the particles and concentration of the filler.

The optimum concentration of fibrous filler (20 wt. \%) which corresponds to the formation of a homogeneous composite structure and the necessary physical-mechanical and tribotechnical properties was found.

The task of increasing the breaking strength and wear resistance of the polymer composition by preliminary mechanical activation matrix (PTFE) and fillers before their mixing was posed as the basis of this work.

The task was achieved by improving the technology of preparation of the filler and mixing modified ingredients of composition by the energy impact.

Fragments of CF were activated in high-speed mill 
in mode $n=7 \cdot 10^{3} \mathrm{~min}^{-1}$ and $\tau=9$ minutes.

Activated fragments of CF (20 wt. \%) were mixed with the previously activated by the author technology powder PTFE [7] (80 wt. \%) in the high-speed mixer in mode $n=7 \cdot 10^{3} \mathrm{~min}^{-1}$ and $\tau=5$ minutes.

Electron microscopic studies of the fragment of $\mathrm{CF}$ after such mechanical activation showed (Fig. 2) that the character of the fiber surface before grinding (Fig. 2a) is significantly different from the character of the surface of activated fiber (Fig. 2b): fiber structure becomes «fluffier», its area increases (Fig. 2b) and this contributes to a more active interaction between PTFE and fragments of $\mathrm{CF}$ and increasing their mutual adhesion.

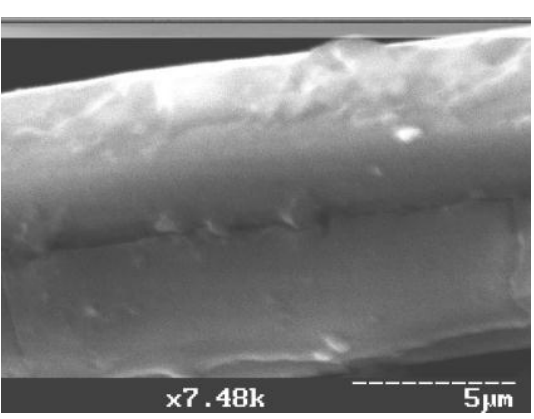

a

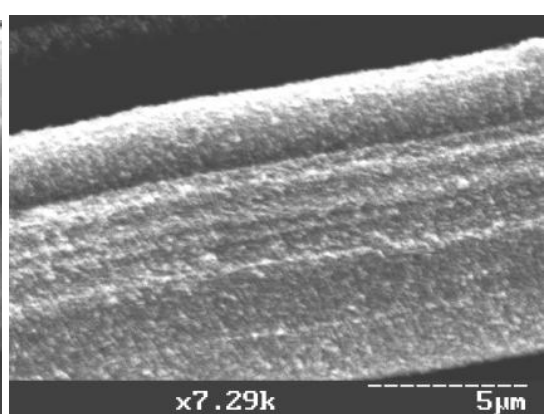

$\mathrm{b}$

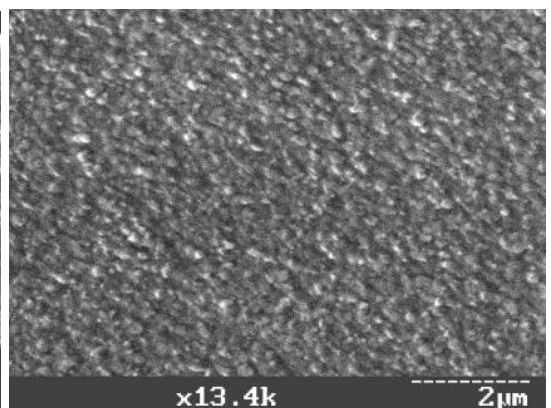

Fig. 2 - Microphotographs of the surface of the fragments CF before (a) and after (b, c) mechanical activation in mode $n=7 \cdot 10^{3} \mathrm{~min}^{-1}$ and $\tau=9$ minutes

Obviously, this is due to the fact that the structure of the fragments of $\mathrm{CF}$ is a fibrous $[12,13]$. Fibrils are composed from the ribbon graphite layers of the condensed carbon (Fig $2 \mathrm{~b}$ ). These layers are separated by a long $(20,0-30,0 \mathrm{~nm})$ and narrow pores (diameter 1,5-2 $\mathrm{nm}$ ), the orientation of which coincides with the orientation of the fibrils. The total volume of pores in the carbon fiber is ranging from 5 to $30 \%$. Mechanical activation of the fragments of CF leads to the explosive disturbance these pores and appearance on the fiber surface "plowed» relief.

For prevention the formation of free radicals the chemical bonds on the surface of grinding filler and its deactivation it was suggested to perform the grinding filler in situ, - that is, in the presence of small impurities (about 1 wt. \%) of PTFE. Then additionally injected necessary compounding quantity of PTFE (optimal 1:4).

As result of this technological reception was received modified carbon fiberfill coated with a layer of activated PTFE (Fig. 3).

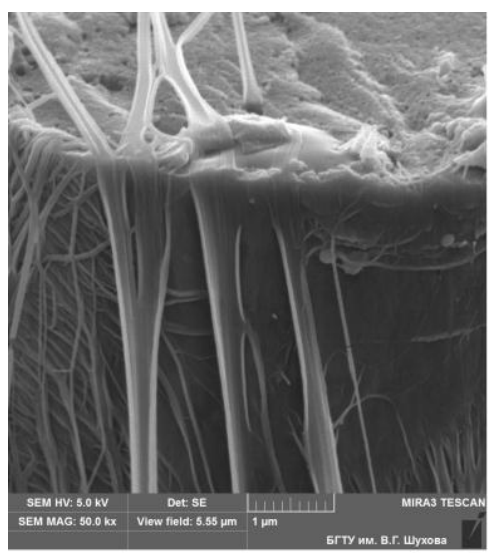

Fig. 3-Microphotograph of the surface of the fragments CF modified by technology in situ
Thus, in the process of the energy impact on the composition as a result of mechanical sequential activation of the ingredients before their combination (mixing) there is a growth of free surface energy, dispergating and changing their shape. Mechanical load leads to appearance of the metastable conditions surface layers [4]. All these phenomena cause the appearance on the surface of the filler particles uncompensated valences, which promote interaction of the filler particles with a matrix and initiating the polymerization reaction of monomers or the formation of chemical bonds with polymer radicals [14].

Simultaneously with the activation process of the fillers, takes place the chemical mechanical destruction of macromolecules polytetrafluoroethylene with the formation of radical fragments. Availability, on the one hand, the active surface of fillers and with another free radical of the polymer macromolecule can initiate the reaction of vaccination of polymer to the filler [16]. Although such reactions with the formation of chemical bonds between polymer and filler surface are passing only on the active centers and have the probable character, however their contribution to the creation of the strengthened composite material quite substantial.

Methods of electron microscopy (Fig. 3) was established the formation on the surface of the fragments of CF more stable intermediate layer of polytetrafluoroethylene (Fig. 3b), than without their activation (Fig. 3a), that "cures» the defects of the fillers and promotes the formation of a stable spacious cluster of filler in the volume of matrix composition.

Constructional fibrous composites based on PTFE during its formation as a composition absorb the nanostructured components of $\mathrm{CF}$, which go beyond fiber and penetrate into the interphase boundary of partition and the matrix. This allows achieving maximum reinforcing effect and, thus, increasing the strength characteristics of the composite and its wear resistance (Table 1$)$. 


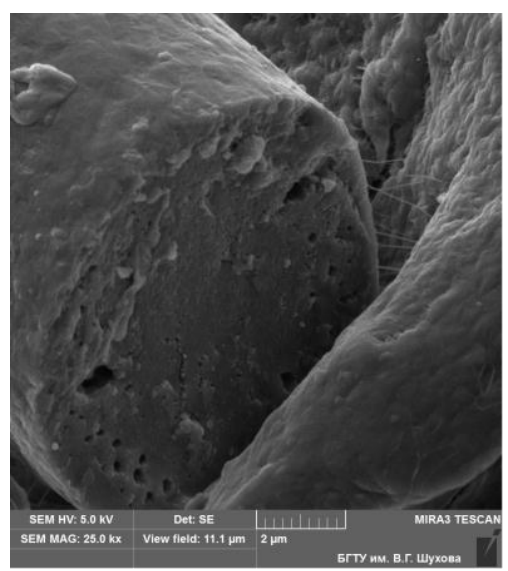

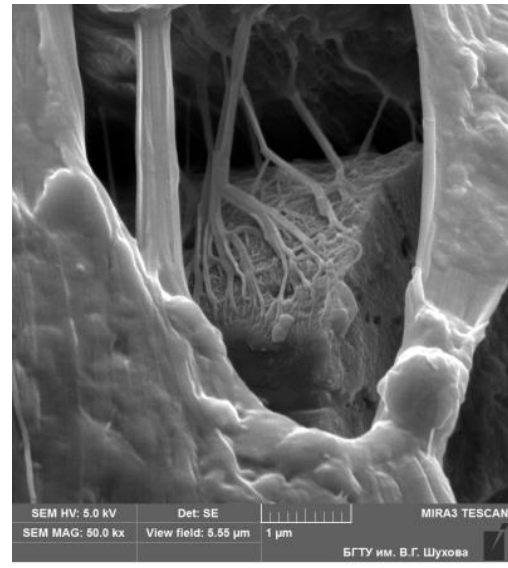

Fig. 4 - Microphotographs of the composite structure according to technology of obtaining: a) activated PTFE + fragments of CF; b) activated PTFE + activated fragments of CF

Table 1 - Influence of mechanical activation the ingredients composition on its mechanical-physical and tribotechnical properties

\begin{tabular}{|c|c|c|c|c|}
\hline Composite ingredients & $\begin{array}{c}\text { Density } \rho, \\
\mathrm{g} / \mathrm{cm}^{3}\end{array}$ & $\begin{array}{c}\text { Breaking } \\
\text { strength } \sigma, \mathrm{MPa}\end{array}$ & $\begin{array}{c}\text { Relative elon- } \\
\text { gation } \delta, \%\end{array}$ & $\begin{array}{c}\text { Wear intensity } \\
I \cdot 10^{-6}, \mathrm{~mm}^{3} / \mathrm{N} \cdot \mathrm{m}\end{array}$ \\
\hline $\begin{array}{c}80 \% \text { PTFE (activated) + } \\
20 \text { fragments of CF (activated) }\end{array}$ & 1,97 & 24,2 & 154 & $3,5-6,5$ \\
\hline $\begin{array}{c}80 \% \text { PTFE (activated) } \\
20 \% \text { fragments of CF }\end{array}$ & 1,98 & 22,1 & 145 & $16-38$ \\
\hline $\begin{array}{c}80 \% \text { PTFE + 20 \% CF (control) } \\
\text { (TC 301-05-16-89) }\end{array}$ & 1,98 & $12-13$ & 20 & $75-85$ \\
\hline
\end{tabular}

Thus, mechanical activation method of obtaining composite greatly transforms weekend particle of the fragments of CF transforming them into a structure that are covered with a thin, nanoscale layer of PTFE. These formations are active nanofillers of PTFE, which significantly (by 20-45 \%) increase its physical-mechanical and performance properties.

\section{CONCLUSIONS}

The results of research allowed making the following conclusions:

1. Studies have opened the possibility of using nanostructured activated PTFE as a matrix of fluoropolymer composites of fluoropolymer composites in order to obtain a composite material with high physical and mechanical properties for friction joints of machinery and equipment for various purposes.

2. Performed obtained modes of process technological equipment, which after processing on it activated PTFE with nanoscale structure has elevated the performance properties compared to the baseline, and may be used to produce composites based on it with maximum efficiency.
3. It was established that the formation of the optimal nanostructure of PTFE composite with fragments of CF is completed after mode $n=7 \cdot 10^{3} \mathrm{~min}^{-1}$ during $\tau=9$ minutes.

4. It is shown that modification of nanofiller by its surface processing of PTFE activated powder in obtaining in situ improves the physical-mechanical and tribotechnical properties of the composite by increasing adhesion ability of the filler.

5. As a result of the energy influence on the composition - sequential mechanical activation of the ingredients (PTFE and $\mathrm{CF}$ ) before their mixing was obtained a material of new generation which has the physical-mechanical and performance properties by $20-45 \%$ higher compared to the material of old generation F4CF20 (TC 6-05-041-937-86).

\section{ACKNOWLEDGMENTS}

The work was done in the framework of the state assignment of Ministry of Education and Science of Ukraine (theme No 0115U000680C, deadline 01.01.2015-31.12.2016) 


\title{
Наноструктурна модифікація політетрафторетилену та його композиції енергетичним впливом
}

\author{
Х.В. Берладір ${ }^{1}$, Т.П. Говорун ${ }^{1}$ В.А. Свідерський${ }^{2}$ П.В. Руденко ${ }^{1}$, М.Є. Вишегородцева ${ }^{1}$ \\ ${ }_{1}^{1}$ Сумський держсавний університет, вул. Римського-Корсакова, 2, 40007 Суми, Украйна \\ ${ }^{2}$ Національний технічний університет Украйни "Київський політехнічний інститут", пр. Перемоги, 37, \\ ОЗ056 Київ, Україна
}

\begin{abstract}
Досліджено надмолекулярну структуру та експлуатаційні властивості активованого матричного політетрафторетилену, модифікованого волокнистого наповнювача та композитів на їх основі. Показано, що енергетичний вплив сприяе переведенню структури матричного політетрафторетилену у нанорозмірний стан. Розроблена технологія почергової механічної активації інгредієнтів композиції перед їх суміщенням шляхом енергетичного впливу. Наноструктуровані матриця, фрагменти вуглецевих волокон і межі їх розділу у сформованому композиті зумовлюють унікальність фізико-механічних та експлуатаційних характеристик композитних матеріалів. В результаті досліджень розроблено матеріал нового покоління з максимумом фізико-механічних та триботехнічних властивостей.
\end{abstract}

Ключові слова: Політетрафторетилен, Фрагменти вуглецевих волокон, Наноструктура, Активовані інгредієнти, Механічна активація, Властивості, Матеріал нового покоління.

\section{Наноструктурная модификация политетрафторэтилена и его композиции энергетиче- ским воздействием}

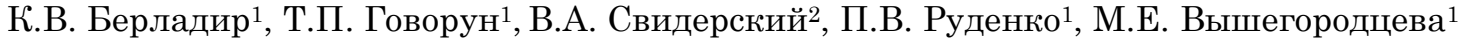 \\ 1 Сулский государственный университет, ул. Рилского-Корсакова, 2, 40007 Сумь, Украина \\ ${ }^{2}$ Национальный технический университет Украины "Киевский политехнический институт", \\ просп. Победь, 37, 03056 Киев, Украина
}

\begin{abstract}
Исследовано надмолекулярную структуру и эксплуатационные свойства активированного матричного политетрафторэтилена, модифицированного волокнистого наполнителя и композитов на их основе. Показано, что энергетическое воздействие способствует переводу структуры матричного политетрафоторэтилена в наноразмерное состояние. Разработана технология последовательной механической активации ингредиентов композиции перед их совмещением путем энергетического воздействия. Наноструктурированные матрица, фрагменты углеродных волокон и границы их раздела в сформированном композите обусловливают уникальность физико-механических и эксплуатационных характеристик композитных материалов. В результате исследований разработан материал нового поколения с максимумом физико-механических и триботехнических свойств.
\end{abstract}

Ключевые слова: Политетрафторэтилен, Фрагменты углеродных волокон, Наноструктура, Активированные ингредиенты, Механическая активация, Свойства, Материал нового поколения.

\section{REFERENCES}

1. S.V. Avdeychik, Engineering fluorocomposites: structure, technology, application (Grodno: YKSUG GrSU of the Yanka Kupala: 2012).

2. P.M. Ajayan, L.S. Schadler, P.V. Braun, Nanocomposite Science and Technology (Weinheim.: WILEY-VCH Verlag GmbH \& Co. KGaA: 2003).

3. A.D. Pogrebnjak, V.M. Beresnev, Nanocoatings, nanosystems, nanotechnologies (Sharjah: Bentham Sci.: 2012).

4. N.K. Baramboym, Mechanochemistry of macromolecular compounds (Moscow: Chemistry: 1978).

5. A.K. Pugachev, O.A. Roslyakov, Processing of thermoplastics products (Moscow: Chemistry: 1987).

6. I.V. Kragelskiy, M.N. Dobychin, V.S. Kambalov, The basis of calculation for friction and wear (Moscow: Mechanical engineering: 1977).

7. Y.P. Adler, Introduction to experimental design (Moscow: Metallurgy: 1965).
8. A.F. Budnik,

K.V. Berladir,

P.V. Rudenko, V.A. Sviderskiy, Pat. 101976, Ukraine, MPK(2006.01): C08J5/04, publ. 12.10.2015, bull. No 19/2015.

9. O.A. Budnik, A.F. Budnik, P.V. Rudenko, V.A. Sviderskiy, K.V. Berladir, Funct. J. 22 No 4, 499 (2015).

10. A.F. Budnik, P.V. Rudenko, K.V. Berladir, O.A. Budnik, J. Nano- Electron. Phys. 7 No 2, 02022 (2015).

11. A. Fourdeux, R. Perret, W. Ruland, First International Conference on Carbon Fibers, 57 (London: Plastics Institute: 1971).

12. V.Ya. Varshavskiy, Carbon fiber (Moskva: Varshavskiy: 2007).

13. A.I. Gusev, Nanomaterials, nanostructures, nanotechnology (Moskva: Fizmatlit: 2005).

14. A.D. Pogrebnjak, A.P. Shpak, N.A. Azarenkov, V.M. Beresnev, Phys. Usp. 52 No 1, 29 (2009). 